\title{
Coronavirus-Like Particles and Campylobacter in Marmosets with Diarrhea and Colitis
}

\author{
R.G. RUSSELL, DVM, PhD, D.A. BRIAN, DVM, PhD, A. LENHARD, DVM, L.N.D. POTGIETER, \\ BVSc, PhD, D. GILLESPIE, DVM, and N.K. CLAPP, DVM, PhD
}

Diarrhea and colitis were common clinical entities observed during a recent two-year interval in the marmoset colony located at Oak Ridge Associated Universities, Oak Ridge, Tennessee. The diarrhea occurred in sporadic episodes of several weeks duration and affected up to $5 \%$ of all animals at any one time. The incidence of the colitis is unknown, but it appeared to be widespread. Histologically, the colitis was similar to that described in cottontop tamarins (Saguinus oedipus oedipus) at the New England Primate Center (1). There was infiltration of predominantly mononuclear cells into the interstitium, dilation of crypts with flattened epithelium, and accumulation of neutrophils and degenerated and necrotic epithelial cells in the lumen (2). The cause of either the diarrhea or the colitis is not known, nor is it known to what extent they are causally related.

In this report we describe studies demonstrating both coronavirus-like particles and Campylobacter in marmosets with diarrhea. Coronavirus-like particles were found in $24 \%$ and Campylobacter fetus subsp. jejuni in $20 \%$ of sampled animals with diarrhea. Immunoblotting studies on serum from a

From the Departments of Pathobiology, Microbiologý, and Environmental Practice, College of Veterinary Medicine, University of Tennessee, Knoxville, Tennessee 37996; and Oak Ridge Associated Universities, Oak Ridge, Tennessee 37831.

Suppported by a grant from the National Foundation for Ileitis and Colitis, Inc., by Oak Ridge Associated Universities Corporation, by contract DE-AC05-760R00053 between the Department of Energy, Office of Energy Research, and Oak Ridge Associated Universities, and by National Cancer Institute, DHHS, grant N01-CP-21004.

Address correspondence and reprint requests: Dr. R.G. Russell, Division of Animal Science SB-42, School of Medicine, University of Washington, Seattle, Washington 98195. small number of animals having diarrhea suggested the presence in the colony of antibodies to a coronavirus antigenically related to the bovine enteric coronavirus but not the porcine transmissible gastroenteritis virus. Interestingly, all of the seven animals that died and exhibited histopathological lesions of colitis had coronavirus-like particles in their colon contents.

\section{MATERIALS AND METHODS}

Marmosets and Collection of Fecal Samples. A colony of approximately 500 marmosets is housed at the Marmoset Research Center, Oak Ridge Associated Universities, Oak Ridge, Tennessee. These include the tamarins Saguinus oedipus oedipus, Saguinus fuscicollis spp., and the common marmoset Callithrix jacchus. Animals are housed either singly in cages or as families in the breeding facility. Stool samples were taken from 107 animals during a two-year period over which episodes of diarrhea occurred. During one episode lasting two months, 30 samples were taken, 17 of these being collected over a three-day period. All stool samples were obtained from adult marmosets $1-15$ years of age either during signs of diarrhea or within one week of recovery. Colon contents were collected at necropsy from eight marmosets that died spontaneously. The necropsy diagnosis of these animals is discussed in the Results section.

Culturing for Enteropathogenic Bacteria. Samples of feces were cultured at $37^{\circ} \mathrm{C}$ on MacConkeys or heptone agar, or on selenite broth followed by subcultures, for Salmonella and Shigella. Samples were also cultured at $42^{\circ} \mathrm{C}$ under microaerophilic 
conditions on commercial Campylobacter enrichment medium (Campy-bap, BBL) with $10 \%$ sheep red blood cells for the isolation of Campylobacter sp.

Electron Microscopy. Stool samples were suspended in four volumes of distilled water, clarified at $100^{\circ} \mathrm{g}$ for $5 \mathrm{~min}$, and $5 \mathrm{ml}$ was pelleted at 15,000 $g$ in a Beckman SW-50 rotor for $1 \mathrm{hr}$. The resulting pellet was suspended in $0.5 \mathrm{ml}$ distilled water and 50 $\mu l$ of this was mixed with $50 \mu$ of $2 \%$ phosphotungstic acid ( $\mathrm{pH} \mathrm{6.8,} \mathrm{adjusted} \mathrm{to} \mathrm{this} \mathrm{pH}$ by the addition of potassium hydroxide). The mixture was then sprayed from a glass nebulizer onto Formvar-coated copper grids. Electron microscopy was done on a Phillips $201 \mathrm{C}$ electron microscope.

Growth and Purification of Virus, Polyacrylamide Gel Electrophoresis, and Immunoblotting. A plaquepurified stock of the bovine enteric coronavirus (BCV; Mebus strain) was grown on the human rectal tumor cell line (HRT-18) (3) using previously described methods (4). Cells were grown on Dulbecco's modified minimum essential medium (DMEM) with $10 \%$ fetal bovine serum (Sterile Systems, Inc.). Cells were infected with a multiplicity of 1 , and supernatant fluids were harvested at $48-72 \mathrm{hr}$ postinfection, and clarified at $10,000 \mathrm{~g}$ for $5 \mathrm{~min}$. A plaque-purified stock of the porcine transmissible gastroenteritis virus (TGEV; Purdue strain) was grown on the swine testicle cell line (ST) (5) using previously described methods (6). Cells were grown on DMEM with $10 \%$ adult bovine serum (Sterile Systems, Inc.). Cells were infected with a multiplicity of 1 , and supernatant fluids were harvested at 18-24 hr postinfection, and clarified at $10,000 \mathrm{~g}$ for $5 \mathrm{~min}$. Each virus was separately pelleted in $38-\mathrm{ml}$ tubes on a Sorval 627 rotor at $26,000 \mathrm{rpm}, 2 \mathrm{hr}$, at $4^{\circ} \mathrm{C}$ through a 3-ml cushion of $20 \%$ sucrose $\mathrm{w} / \mathrm{w}$ in TMEN-6 buffer [ $50 \mathrm{mM}$ Tris acid

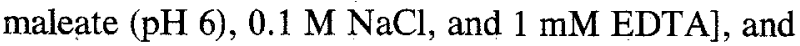
the pellet was dissolved in sample treatment buffer [62.5 mM Tris hydrochloride (pH 6.8), 2\% SDS, $5 \mathrm{M}$ urea] and diluted with sample treatment buffer until the concentration of viral protein was approximately $15 \mu \mathrm{g} / \mu \mathrm{l}$ as determined by Coomassie blue staining of $1-\mu \mathrm{l}$ aliquots on nitrocellulose (7).

Viral proteins were electrophoretically separated using the discontinuous buffer method of Laemmli (8). Approximately $1.2 \mathrm{mg}$ of viral protein was spread along a continuous well of a vertical slab $(0.75 \times 100 \times 160 \mathrm{~mm})$ electrophoresis apparatus (Hoeffer Scientific Instruments) and electrophoresed through a $1-\mathrm{cm}$ stacking gel of $3 \%$ polyacrylamide and an $8-\mathrm{cm}$ separating gel of $9 \%$ polyacryl- amide. Electrophoretic transfer of viral proteins from polyacrylamide gels to nitrocellulose sheets was done by the method of Burnette (7). Nitrocellulose sheets containing viral proteins were marked for alignment, cut into strips of $5 \mathrm{~mm}$ width, and each strip was incubated with a 1:10 dilution of serum in 15-ml, siliconized, plastic, screw-capped centrifuge tubes. The procedure of Burnette (7) was used for radiodetection of bound immunoglobulins using ${ }^{125}$ I-labeled Staphylococcus-A protein. ${ }^{125} \mathrm{I}$ labeled Staphylococcus-A protein $(2-10 \mu \mathrm{Ci} / \mu \mathrm{g})$ was purchased from ICN. Strips were then exposed to Kodak X-Omat R film for autoradiography.

\section{RESULTS}

Episodes of diarrhea involved approximately $20 \%$ of all animals over a two-year period. The largest episode occurred during a two-month period and involved over 30 animals. Many animals were treated with broad-spectrum antibiotics if diarrhea was accompanied by anorexia, or if diarrhea lasted longer than three days. Because some animals were unresponsive to treatment and had no laboratory evidence of parasites or enteropathogenic bacteria, fecal samples were examined by electron microscopy for evidence of viruses.

Coronavirus-like particles were observed in feces from $24 \%$ of the 58 samples examined by electron microscopy (Table 1). The particles measured approximately $100-220 \mathrm{~nm}$ and had regularly spaced petal-shaped projections from the surface (Figure 1). Some also appeared to have an indentation of the surface and some were interpreted as having an empty nucleocapsid (Figure 1). In three samples, a reovirus-like particle was found, but no other viruslike agents were observed.

Fecal specimens from 65 marmosets with similar clinical signs were cultured bacteriologically. They were consistently negative for Salmonella and Shigella. Campylobacter fetus subsp. jejuni was isolated from $20 \%$ of the stool samples (Table 1). Of 16 marmosets examined for both viral and bacteriological agents, only one was found to have both coronavirus-like particles and Campylobacter.

The colon contents of eight animals that died were collected at necropsy and examined for the presence of coronavirus-like particles. Of these, seven had mild to moderate enterocolitis histologically (Table 2). Interestingly, all seven animals having colitis also had coronavirus-like particles in their colonic contents (Table 2). 
Table 1. Coronavirus-Like Particles and Campylobacter in Stool Samples from MARMOSETS haVING DIARRHEA

\begin{tabular}{|c|c|c|c|c|c|c|}
\hline \multirow{2}{*}{\multicolumn{2}{|c|}{$\begin{array}{l}\text { Examination of stools } \\
\text { by } E M^{*} \text { only } \\
\end{array}$}} & \multicolumn{3}{|c|}{$\begin{array}{c}\text { Examination of stools by EM and } \\
\text { bacterial culture }\end{array}$} & \multirow{2}{*}{\multicolumn{2}{|c|}{$\begin{array}{c}\text { Examination of stools } \\
\text { by bacterial culture } \\
\text { only }\end{array}$}} \\
\hline & & & Number & Number & & \\
\hline $\begin{array}{l}\text { Number of } \\
\text { animals }\end{array}$ & $\begin{array}{l}\text { Number } \\
\text { positive }\end{array}$ & $\begin{array}{l}\text { Number of } \\
\text { animals }\end{array}$ & $\begin{array}{l}\text { positive } \\
\text { corona }\end{array}$ & $\begin{array}{c}\text { positive } \\
\text { Campylobacter }\end{array}$ & $\begin{array}{l}\text { Number of } \\
\text { animals }\end{array}$ & $\begin{array}{l}\text { Number } \\
\text { positive }\end{array}$ \\
\hline 42 & 7 & 16 & 7 & 1 & 49 & 13 \\
\hline
\end{tabular}

*EM, electronmicroscopy.

Initial attempts to grow the coronavirus-like agent in tissue culture have not been successful. The feces of five separate animals demonstrating coronavirus-like particles by electron microscopy were used as the virus source and attempts were made on cell cultures of primary marmoset kidney cells, Vero cells, the human rectal tumor cell line-18 (3), the swine testicle cell line of McClurkin and Norman (5), and human rhabdomyosarcoma cells (9).

In an initial attempt to identify the coronaviruslike agents as coronaviruses, serum from 10 marmosets having diarrhea were reacted against viral proteins of the bovine enteric coronavirus and of the porcine transmissible gastroenteritis coronavirus, representatives of the two antigenic subgroups of the mammalian coronaviruses. Coronaviral pro- teins were electrophoretically separated, electrophoresed to nitrocellulose paper, reacted with serum and subsequently with $\left[{ }^{125} \mathrm{I}\right]$ staph $A$ protein. The results of serum from four marmosets are shown in Figure 2. Two of the five proteins of the bovine coronavirus but not of the proteins of the porcine transmissible gastroenteritis coronavirus appeared to bind antibodies in serum from six of 10 animals examined. The results suggest that a coronavirus antigenically related to the bovine coronavirus but not to the porcine transmissible gastroenteritis coronavirus exists in the marmoset colony. Whether these antibodies represent an immune response to the coronavirus-like agents observed in the feces of marmosets remains to be shown.
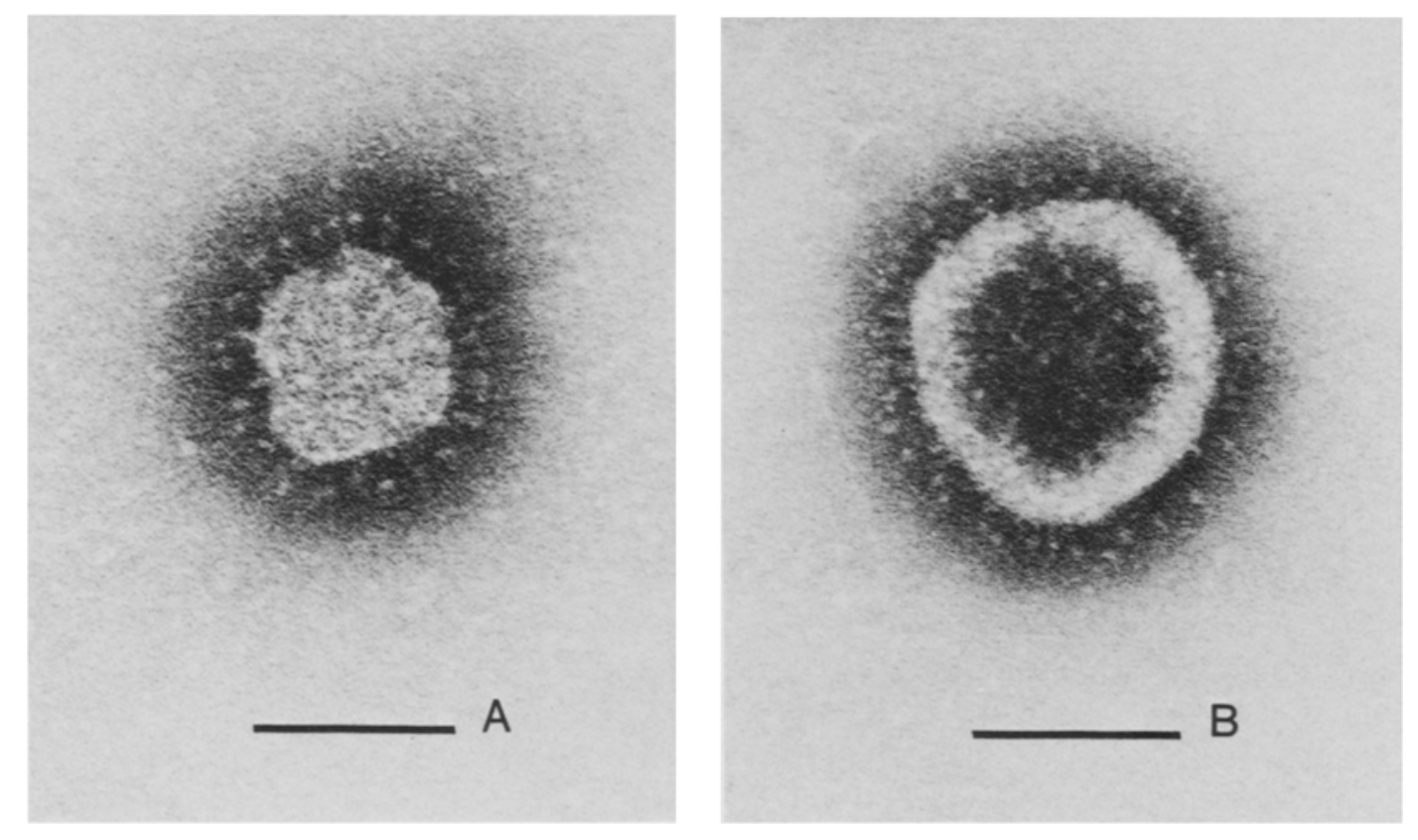

Fig 1. Negatively stained coronavirus-like particles from marmoset diarrheic feces. (A) Spherical particle showing petal-shaped projections. (B) A particle apparently devoid of a nucleocapsid. The bar represents $100 \mathrm{~nm}$. 


\section{CORONAVIRUS-LIKE PARTICLES AND Campylobacter IN MARMOSETS}

Table 2. Summary of Clinical, Pathological, Viral, and Bacteriologic Findings Among 8 Marmosets that Died SPONTANEOUSLY

\begin{tabular}{|c|c|c|c|c|c|}
\hline \multirow[b]{2}{*}{ Clinical Signs } & \multirow[b]{2}{*}{ Pathological Findings } & \multirow[b]{2}{*}{ Age } & \multirow[b]{2}{*}{ Species } & \multicolumn{2}{|c|}{ Examination of colon contents } \\
\hline & & & & $\begin{array}{l}\text { Coronavirus- } \\
\text { like particles }\end{array}$ & $\begin{array}{l}\text { Campylobacter fetus } \\
\text { subsp. jejuni }\end{array}$ \\
\hline Wasting & Emaciated, colitis & 9 years & S. fusc. & + & - \\
\hline $\begin{array}{l}\text { Sudden onset weakness, } \\
\text { dehydration }\end{array}$ & $\begin{array}{l}\text { Emaciated, bronchopneumonia, } \\
\text { moderate enterocolitis, mild } \\
\text { interstitial nephritis }\end{array}$ & 8 years & S. fusc. & + & - \\
\hline Wasting & No significant findings & $11 / 2$ years & S. fusc. & - & ND \\
\hline Emaciation & Renal amyloidosis, moderate colitis & 11 years & S. oed. & t & ND \\
\hline Emaciation & Lymphosarcoma, moderate colitis & Adult & S. oed. & + & ND \\
\hline Wasting, emaciation & Colon adenocarcinoma & 8 years & S. oed. & + & ND \\
\hline Wasting, diarrhea & $\begin{array}{l}\text { Emaciated, moderate enterocolitis, } \\
\text { intussusception }\end{array}$ & 8 years & C. jacc. & + & ND \\
\hline Acute diarrhea & Acute enterocolitis & 9 months & C. jacc. & + & + \\
\hline
\end{tabular}
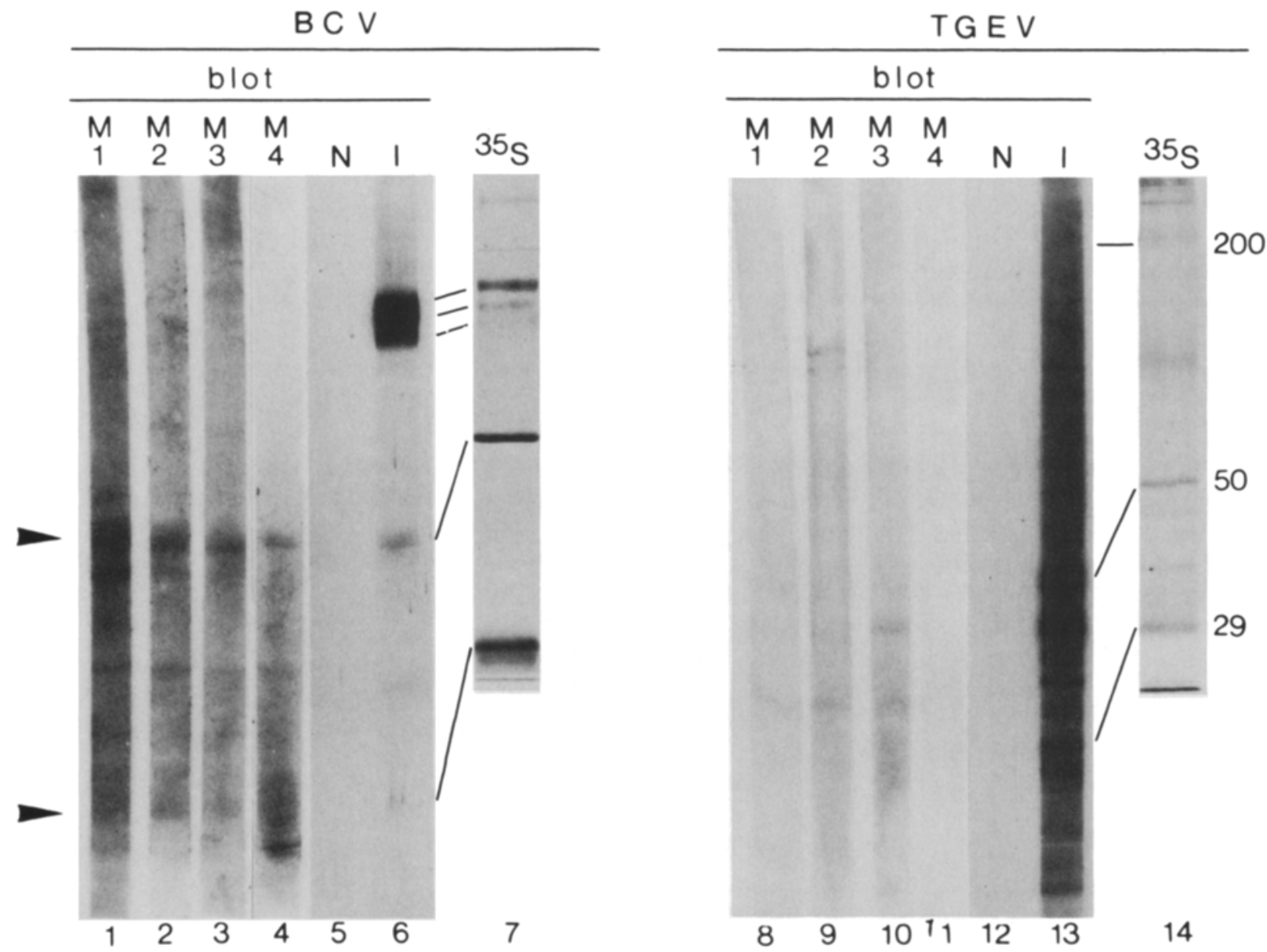

Fig 2. Immunoblots of marmoset serums against the proteins of the bovine enteric coronavirus $(\mathrm{BCV})$ and the porcine transmissible gastroenteritis virus (TGEV). In lanes $1-4$ and 8-11 serums from four separate marmosets who had diarrhea were used Coronavirus-like particles were found in the feces of animals number 3 and 4 . In lane 5 serum from the preimmunized rabbit and in lane 6 serum from the rabbit immunized with purified BCV were used. Lane 7 (inset) is an electropherogram of ${ }^{35} \mathrm{~S}$-labeled, purified BCV. In lane 12 serum from nonimmune newborn piglet and in lane 13 from a gnotobiotic pig hyperimmunized with TGEV were used. Lane 14 (inset) is an electropherogram of ${ }^{35} \mathrm{~S}$-labeled, purified TGEV. 


\section{DISCUSSION}

We describe coronavirus-like particles and Campylobacter in the feces of marmosets suffering diarrhea and colitis. To date no firm association can be drawn between either agent and the diarrhea or either agent and the colitis, but our results do allow us to design approaches to investigate possible causal relationships.

The virus-like particles observed in fecal and colonic specimens were interpreted as probable coronavirus because of the ultrastructural morphology. These particles must be differentiated from fringed particles that are of nonviral origin (10). To confirm the existence of coronaviruses, two approaches should be taken: (1) The coronavirus should be grown in tissue culture and further characterized at the molecular level. Initial attempts have not yet been successful on primary marmoset cells and on cell lines of other animal species. Inasmuch as replication of coronaviruses is enhanced on transformed cells (11), transformed marmoset cells should be tried. (2) Serum from a variety of colony animals should be used to attempt precipitation of viral particles by immune electron microscopy (10). Evidence of immune clumping by antibody would support the notion that the observed coronavirus-like particles are infectious agents. Further precipitation with known antiserum to other coronaviruses should be attempted for classification of these agents.

Initial attempts have been made to identify the presence of coronavirus antibodies in the marmoset colony. Whereas no attempt has yet been made to react marmoset serum with the coronavirus-like particles observed in marmoset feces, marmoset serum was used to identify serological reactivity to the bovine enteric coronavirus and to the porcine tranmissible gastroenteritis coronavirus, each a representative of the two antigenic subfamilies of mammalian coronaviruses (12). Reactivity in six marmosets was observed for the internal 50-kd phosphoprotein and the $26-\mathrm{kd}$ glycoprotein of the bovine coronavirus but not to any identifiable protein of the porcine gastroenteritis coronavirus. Since the 50-kd and 26-kd proteins are largely internal virion proteins (4), they probably represent evolutionarily conserved proteins within this antigenic subgroup of coronaviruses.

Further investigation is necessary to establish the role of the coronavirus-like particles in both the diarrhea and the colitis observed in the marmosets.
Coronaviruses have been established as the cause of acute diarrhea in many animal species $(13,14)$. Their presence in the stools of humans with nonbacterial gastroenteritis suggests they may be a cause of acute diarrhea in humans too (15-19). They have been found in the stools of nonhuman primates with diarrhea, but their role in this disease was not obvious since they were also found in the stools of nondiseased animals (20). The role of coronaviruses in chronic gastrointestinal disease in animals and man has been more difficult to establish. Persistent shedding of coronaviruses from many animal species is documented, but no correlation with chronic intestinal disease has yet been made $(13,21)$. Persistent shedding of coronavirus-like particles was observed over an eight-month period in a human individual with chronic intestinal maladsorption and suggests a possible role by coronaviruses in this disease (22).

The role of Campylobacter in marmoset diarrhea likewise needs further investigation. Campylobacter has been described as the most common bacterial cause of acute enterocolitis in man $(23,24)$. Histopathological findings in the large bowel for this disease are mild to moderate infiltration of mononuclear cells, neutrophils, and eosinophils in the lamina propria; cryptitis; and crypt abscesses (25-27). Age groups affected are mainly teens and adults, although cases have been reported in infants and children. Infection is usually not severe and is generally self-limiting $(23,24)$. Campylobacter has been implicated in persistent and recurrent diarrhea of infants and adults $(28,29)$. Campylobacter also has been implicated in acute and persistent diarrhea in nonhuman primates (30-34), but its high prevalence in apparently normal animals makes it difficult to establish its role in chronic disease $(34,35)$. Experimental infection has not been successful in some studies (36), although oral infection of young nonhuman primates with a human isolate caused mild disease of short duration (35). Histopathologic findings were absent in experimentally infected Macaca mulatta (35). Mild nonsuppurative enteritis was reported in Erythrocelous patus monkeys with persistent diarrhea from which Campylobacter was isolated (32).

\section{ACKNOWLEDGMENTS}

We thank John Norman for excellent technical assistance. Supported by a grant from the National Foundation for Ileitis and Colitis, Inc., by Oak Ridge Associated Universities Corporation, by contract DE-AC05- 
760R00053 between the Department of Energy, Office of Energy Research, and Oak Ridge Associated Universities, and by National Cancer Institute, DHHS, grant N01-CP-21004.

\section{REFERENCES}

1. Chalifoux LV, Bronson RT, Escajadillo A, McKenna S: An analysis of the association of gastroenteric lesions with chronic wasting syndrome of marmosets. Vet Pathol 19(Suppl 7):141-162, 1982

2. Lushbaugh CC, Clapp NK: Histology of colitis: Saguinus oedipus oedipus and other marmosets. Dig Dis Sci (this issue)

3. Tompkins WAF, Watrach AM, Schmale JD, Schulze RM, Harris JA: Cultural and antigenic properties of newly established cell strains derived from adenocarcinomas of the human colon and rectum. J Natl Cancer Inst 52:101-106, 1974

4. King B, Brian DA: Bovine coronavirus structural proteins. $J$ Virol 42:700-707, 1982

5. McClurkin AW, Norman JO: Studies on transmissible gastroenteritis of swine. II. Selected characteristics of a cytopathogenic virus common to five isolates from transmissible gastroenteritis. Can J Comp Med Vet Sci 30:190-198, 1966

6. Brian DA, Dennis DE, Guy JS: Genome of porcine transmissible gastroenteritis virus. J Virol 34:410-415, 1980

7. Burnette WN: "Western blotting": Electrophoretic transfer of proteins from sodium dodecyl sulfate-polyacrylamide gels to unmodified nitrocellulose and radiographic detection with antibody and radioiodinated protein A. Anal Biochem 112:195-203, 1981

8. Laemmli UK: Cleavage of structural proteins during the assembly of the head of bacteriophage T4. Nature 227:680685,1970

9. Schmidt OW, Kenny GE: Polypeptides and functions of antigens from human coronaviruses $229 \mathrm{E}$ and OC43. Infect Immun 35:512-522, 1982

10. Almeida JD: Uses and abuses of diagnostic electron microscopy. Curr Top Microbiol Immunol 104:147-158, 1983

11. Sturman LS, Takemoto KK: Enhanced growth of a murine coronavirus in transformed mouse cells. Infect Immun 6:501-507, 1972

12. Pederson NC, Ward J, Mengeling WL: Antigenic relationship of the feline infectious peritonitis virus to coronavirus of other species. Arch Virol 58:45-53, 1978

13. Wege H, St. Siddell $S$ ter, Muelen V: The biology and pathogenesis of coronaviruses. Curr Top Microbiol Immunol 99:165-200, 1982

14. Pederson NC, Boyle BF, Floyd K, Fudge A, Barker J: An enteric coronavirus infection of cats and its relationship to feline infectious peritonitis. Am J Vet Res 42:368-377, 1981

15. Caul EO, Paver WK, Clark SKR: Coronavirus particles in faeces from patients with gastroenteritis. Lancet 1:1192, 1975

16. Mathan M, Mathan VI, Swaminathan SP, Jesudoss S, Baker SJ: Pleomorphic virus-like particles in human faeces. Lancet $1: 1068,1975$
17. Moore B, Lee $\mathrm{P}$, Hewish $\mathrm{M}$, Dixon B, Mukherjee T: Coronaviruses in training center for intellectually retarded. Lancet 1:261, 1977

18. Schnagel RD, Holmes IH, Mackay-Scollary EM: Coronavirus-like particles in aboriginals and non-aboriginals in western Australia. Med J Aust 1:307-309, 1978

19. Puel JMC, Orillac MS, Bauriaud RM: Occurrence of viruses in human stools in Ahaggar (Algeria). J Hyg 89:171-174, 1982

20. Smith GC, Lester TL, Heberling RL, Kalter SS: Coronavirus-like particles in nonhuman primate feces. Arch Virol 72:105-111, 1982

21. Hoshino Y, Scott FW: Corona-like virus particles in the feces of normal cats. Arch Virol 63:147-152, 1980

22. Baker SJ, Mathan M, Mathan VI, Jesudoss S, Swaminathan SP: Chronic enterocyte infection with coronavirus. One possible cause of the syndrome of tropical sprue? Dig Dis Sci 27:1039-1043, 1982

23. Skirrow MB: Campylobacter enteritis-the first five years. J Hyg 89:175-184, 1982

24. Walder M: Epidemiology of Campylobacter enteritis. Scand J Infect Dis 14:27-33, 1982

25. Price AB, Jewkes J, Sanderson FJ: Acute diarrhea: Campylobacter colitis and the role of rectal biopsy. $\mathrm{J}$ Clin Pathol 32:990-997, 1979

26. Colgan T, Lambert JR, Newman A, Luk SC: Campylobacter jejuni enterocolitis. A clinicopathologic study. Arch Pathol Lab Med 104:571-574, 1980

27. McKendrick MW, Geddes AM, Gearty J: Campylobacter enteritis: A study of clinical features and rectal mucosal changes. Scand J Infect Dis 14:35-38, 1982

28. Wheeler WE, Borchers J: Vibrionic enteritis in infants. Am $J$ Dis Child 101:60-66, 1961

29. Smalley JR, Klish WJ, Brown MR, Campbell MA: Chronic diarrhea associated with Campylobacter. Clin Pediatr 21:220, 1982

30. Tribe GW, Mackenzie PS, Fleming MP: Incidence of thermophilic Campylobacter spp in newly imported simian primates with enteritis. Vet Rec 105:333, 1979

31. Tribe GW, Fleming MP: Biphasic enteritis in imported cynomologus (Macaca fascicularis) monkeys infected with Shigella, Salmonella, and Campylobacter species. Lab Anim 17:65-69, 1983

32. Bryant JL, Stills HF, Lentsch RH, Middleton CC: Campylobacter jejuni isolated from patas monkeys with diarrhea. Lab Anim Sci 33:303-305, 1983

33. Goodwin T, Adams MR, Lehner NDM, Jerome CP: Campylobacter enteritis in patas monkeys. Lab Anim Sci 33:481, 1983

34. Morton WR, Bronsdon M, Mickelsen G, Knitter G, Rosenkranz S, Kuller L, Sajuthi D: Identification of Campylobacter jejuni in Macaca fascicularis imported from Indonesia. Lab Anim Sci 33:187-188, 1983

35. Fitzgeorge RB, Baskerville A, Lander KP: Experimental infection of rhesus monkeys with a human strain of Campylobacter jejuni. J Hyg 86:343-351, 1981

36. Tribe GW, Frank A: Campylobacter in monkeys. Vet Rec 106:365-366, 1980 